\title{
Cytochrome P450 2C9 Measurement
}

National Cancer Institute

\section{Source}

National Cancer Institute. Cytochrome P450 2C9 Measurement. NCI Thesaurus. Code C161355.

The determination of the amount of cytochrome P450 2C9 present in a sample. 